\title{
Peningkatan Motivasi dan Hasil Belajar Mahasiswa Pada Mata Kuliah Bahasa Arab Materi Hiwar dengan Menggunakan Metode Role Play Pada Program Studi Pendidikan Agama Islam Semester II Universitas Muhammadiyah Sumatera Utara
}

\author{
Hasrian Rudi Setiawan dan Zulkarnein Lubis \\ Dosen Fakultas Agama Islam UMSU \\ (Email : hasrianrudisetiawan@gmail.com)
}

\begin{abstract}
ABSTRAK
Penelitian ini memiliki tujuan yaitu untuk meningkatkan motivasi dan hasil belajar mahasiswa serta mempengaruhi pola pikir mahasiswa agar senang belajar secara berkelompok, yang diharapkan dapat menumbuhkan sikap sosial, rasa percaya diri, menumbuhkan semangat, berfikir kreatif dan inovatif.

Adapun penelitian ini dilakukan dengan prosedur yaitu: 1). Melakukan persiapan 2). Merencanakan tindakan yang akan dilakukan selama proses penelitian; 3). Melaksanakan tindakan di kelas sekaligus melakukan observasi atau pengamatan langsung; 4). Refleksi. Kemudian hasil refleksi tersebut yang akan menjadikan dasar untuk melaksanakan atau tidak melaksanakan siklus berikutnya, jika siklus satu sudah berhasil dan mencapai target yang diinginkan maka siklus dihentikan, namun jika siklus satu masih dinilai kurang berhasil maka dilanjutkan ke siklus berikutnya.

Adapun hasil penelitian ini, yaitu: Pertama, Motivasi belajar mahasiswa mengalami peningkatan setelah menggunakan metode role play, yaitu pada siklus I peningkatan motivasi mahasiswa mencapai $80,83 \%$ sedangkan peningkatan motivasi siswa pada siklus II mencapai, 85,97 \%. Kedua, Hasil belajar mahasiswa mengalami peningkatan setelah menggunakan metode role play, yaitu hasil belajar mahasiswa pada siklus I hanya 23 orang mahasiswa yang mendapat nilai tuntas atau mencapai 63,89\%. Sedangkan pada siklus II hasil belajar mahasiswa mengalami peningkatan dibandingkan dengan siklus I, yaitu mencapai 34 orang mahasiswa yang mendapat nilai tuntas atau mencapai $94,44 \%$. Maka dapat disimpulkan bahwa motivasi dan hasil belajar mengalami peningkatan setelah diterapkannya metode role play.
\end{abstract}

Key Words: Motivasi, Hasil Belajar, Metode Role Play

Korespondensi : FAI Universitas Muhammadiyah Sumatera Utara

Jalan Kapten Mukhtar Basri No. 03 Medan

\section{A. Pendahuluan}

\subsection{Latar Belakang Masalah}

Mata kuliah bahasa Arab merupakan salah satu mata kuliah yang diajarkan di Fakultas Agama Islam pada Program Studi Pendidikan Agama Islam. Mata kuliah ini di rasakan sebagai mata kuliah yang sulit bagi mahasiswa, karena bahasa Arab merupakan bahasa asing dan bukan bahasa percakapan yang dilakukan dalam kehidupan sehari-hari pada masyarakat Indonesia. Dalam mata kuliah bahasa Arab mahasiswa 
Peningkatan Motivasi dan Hasil Belajar Mahasiswa Pada Mata Kuliah Bahasa Arab Materi Hiwar dengan Menggunakan Metode Role Play Pada Program Studi

Pendidikan Agama Islam Semester II Universitas Muhammadiyah Sumatera Utara (Hasrian Rudi Setiawan)

dituntut untuk dapat berkomunikasi dalam bahasa Arab dan mahasiswa mampu memahami kaedah-kaedah dalam bahasa Arab, namun dalam praktek perkuliahan hanya membebankan kepada mahasiswa untuk menghafal kosa kata dalam bahasa Arab, sehingga perkuliahan tersebut kurang menarik dan bervariasi.

\section{Keberhasilan}

proses

pembelajaran dalam kegiatan pendidikan pada dasarnya dipengaruhi oleh banyak faktor, di antaranya adalah dosen, mahasiswa, lingkungan, kurikulum, strategi, metode dan media pembelajaran yang efektif yang dapat membantu mahasiswa agar dapat belajar secara optimal dan mampu meningkatkan motivasi dan hasil belajar mahasiswa. Untuk menciptakan pembelajaran yang menarik, dosen harus memilih metode dan media pembelajaran yang tepat sesuai dengan materi pembelajaran yang diajarkan. Selain itu, dosen harus memahami keragaman mahasiswa dalam kelasnya, dengan memahami keragaman mahasiswa, maka dosen dapat merencanakan secara strategis, upaya untuk mencapai target yang ditentukan.

Dalam kegiatan pembelajaran, banyak dosen yang mampu menguasai materi perkuliahan, namun selalu terbentur dalam menyajikan materi perkuliahan yang diajarkan. Karena itu penting kiranya, bagi seorang dosen memiliki kompetensi dan kemampuan profesional yang baik. Biasanya keluhan mahasiswa yang muncul biasanya seperti: sulit memahami apa yang disampaikan oleh dosen, membosankan, kegiatan perkuliahan terasa melelahkan, tumbuh rasa mengantuk bahkan ada pula yang mengeluh karena penjelasan itu terlalu cepat diberikan sehingga tidak dapat diikuti, termasuk hal-hal yang pelik sekali yang hanya dapat dipahami oleh mahasiswa yang paling inteligen saja. ${ }^{1}$ Tegasnya dosen harus mempunyai kompetensi dan kemampuan profesional dalam kegiatan belajar mengajar, sehingga mampu mewujudkan dimensi kehidupan berkualitas pada diri mahasiswa.

Keberhasilan suatu perkuliahan sangat tergantung dari kemampuan mahasiswa dalam menguasai materi perkuliahan tertentu, mahasiswa dikatakan menguasai materi perkuliahan apabila hasil belajar mahasiswa minimal mendapat nilai 75 atau mendapat nilai B. Kemudian dosen dikatakan berhasil mengajarkan mata kuliah bahasa Arab apabila 80\% dari jumlah mahasiswa dalam kelas tersebut mendapat nilai 75 .

Berdasarkan pengamatan penulis, menurut informasi dari Dekan Fakultas Agama Islam, Ketua Program Studi Pendidikan Agama Islam dan dosen mata kuliah Bahasa Arab, kondisi yang dialami oleh mahasiswa

\footnotetext{
1 Nasution, S. (1992). Berbagai Pendekatan dalam Proses Belajar Mengajar. Jakarta: Bumi Aksara, h. 30
} 
adalah kesulitan menerima penjelasan yang disampaikan oleh dosen dan kurangnya minat mahasiswa dalam mengikuti mata perkuliahan bahasa Arab. Apalagi banyak mahasiswa yang cenderung belum dapat memahami materi hiwar, yang merupakan salah satu di antara materi perkuliahan bahasa Arab yang wajib diketahui. Hal ini terlihat dari banyaknya mahasiswa yang mengikuti ujian, baik itu ujian tengah semester (UTS) dan ujian akhir semester (UAS), mendapat nilai rendah. Kemudian pada semester ganjil ketika ujian tengah semester dilakukan hampir $50 \%$ mahasiswa tidak tuntas dalam mata kuliah bahasa Arab.

Berdasarkan kondisi yang dialami oleh mahasiswa di Program Studi Pendidikan Agama Islam menunjukkan bahwa motivasi dan hasil belajar dalam mata kuliah bahasa Arab cenderung kurang maksimal. Salah satu faktor penyebab utama dari kebosanan belajar mata kuliah bahasa Arab, bukan karena tidak bermutunya materi yang disampaikan, akan tetapi banyak disebabkan oleh kegagalan dosen dalam mempergunakan metode, media pembelajaran atau pendekatan yang dipakai.

Berdasarkan hal tersebut, penulis memilih solusi masalah rendahnya motivasi dan hasil belajar mahasiswa dalam mata kuliah bahasa Arab pada materi hiwar yaitu dengan menggunakan metode role play, yaitu suatu metode tiruan yang bersifat drama yang diperankan oleh dua orang atau

lebih

tentang peranan yang berbeda-

beda dalam keadaan tertentu. Dan juga

dapat dilakukan dengan dukungan media pembelajaran.

\subsection{Rumusan Masalah}

Berdasarkan latar belakang permasalahan diatas, maka rumusan masalah dalam penelitian ini adalah apakah dengan menggunakan metode role play dapat meningkatkan motivasi dan hasil belajar mahasiswa pada mata kuliah bahasa Arab materi hiwar pada Program Studi Pendidikan Agama Islam Semester II Universitas Muhammadiyah Sumatera Utara?

\subsection{Tujuan Penelitian}

Berdasarkan rumusan masalah sebagaimana yang dikemukakan di atas, maka tujuan penelitian ini adalah untuk mengetahui motivasi dan hasil belajar mahasiswa sesudah menggunakan metode role play dalam mata kuliah bahasa Arab pada materi hiwar pada Program Studi Pendidikan Agama Islam Semester II Universitas Muhammadiyah Sumatera Utara.

\subsection{Manfaat Penelitian}

Adapun manfaat yang diharapkan penulis dari penelitian ini, baik secara teoritis maupun praktis, yaitu :

1.4.1. Manfaat Teoritis

1) Hasil penelitian ini diharapkan dapat memberikan masukan dalam pengembangan ilmu 
Peningkatan Motivasi dan Hasil Belajar Mahasiswa Pada Mata Kuliah Bahasa Arab Materi Hiwar dengan Menggunakan Metode Role Play Pada Program Studi

Pendidikan Agama Islam Semester II Universitas Muhammadiyah Sumatera Utara (Hasrian Rudi Setiawan)

pengetahuan, selain itu juga dapat memberi pemahaman psikologis terhadap dosen dalam penggunaan metode role play dalam upaya meningkatkan motivasi dan hasil belajar mahasiswa.

2) Untuk mengembangkan metode, strategi dan model pembelajaran yang menyenangkan.

\subsubsection{Manfaat Praktis}

1) Bagi Mahasiswa

a. Meningkatkan motivasi belajar mahasiswa dalam mata kuliah bahasa Arab pada materi hiwar.

b. Meningkatkan hasil belajar mahasiswa dalam mata kuliah bahasa Arab pada materi hiwar.

c. Terselenggaranya proses belajar yang menyenangkan.

2) Bagi Dosen

a. Untuk memperbaiki pembelajaran dan menciptakan kondisi belajar yang menarik dan menyenangkan.

b. Meningkatkan kreativitas dosen dan berupaya menggali pendekatan pembelajaran yang efektif, efisien, bermakna dan menyenangkan.

c. Meningkatkan profesionalisme dosen.

3) Bagi Fakultas Agama Islam UMSU

a. Mewujudkan pembelajaran yang efektif, efisien, bermakna dan menyenangkan di kampus. b. Meningkatkan prestasi kampus sebagai lembaga pendidikan tinggi dengan meningkatnya kemampuan belajar mahasiswa.

c. Sebagai bahan inovasi metode pembelajaran di kampus.

\section{B. Kajian Pustaka}

\subsection{Motivasi Belajar Peserta Didik}

\subsubsection{Pengertian Motivasi Belajar}

Motivasi berasal dari bahasa Latin yaitu dari kata movere yang bermakna bergerak, istilah ini memiliki makna mendorong, mengarahkan tingkah laku manusia. ${ }^{2}$ Dari pengertian motivasi yang dikemukakan di atas, dapat dipahami bahwa motivasi adalah sebagai daya penggerak yang ada dalam diri seseorang untuk melakukan kegiatankegiatan tertentu untuk mencapai suatu tujuan.

Menurut Hamzah B. Uno, motivasi belajar adalah dorongan internal dan eksternal pada peserta didik yang sedang belajar untuk mendapatkan perubahan tingkah laku dengan beberapa indikator, yaitu adanya keinginan berhasil, adanya dorongan dan kebutuhan dalam belajar, adanya harapan dan cita-cita masa depan, adanya penghargaan, adanya kegiatan yang menarik dalam belajar dan adanya lingkungan belajar yang kondusif sehingga

\footnotetext{
2 Iskandar. (2009). Psikologi Pendidikan Sebuah Orientasi Baru. Ciputat: Gaung Persada Press, h. 26
} 
memungkinkan seseorang peserta didik dapat belajar dengan baik. ${ }^{3}$ Dapat pengertian tersebut dapat dipahami bahwa, motivasi dalam belajar merupakan daya penggerak dari dalam diri individu untuk melakukan kegiatan belajar untuk menambah pengetahuan dan keterampilan serta pengalaman.

\subsubsection{Sumber-sumber Motivasi dalam Pembelajaran}

Dalam kegiatan belajar ada dua jenis sumber motivasi, yaitu: Pertama, Motivasi Internal (Intrinsik Motivation). Motivasi internal merupakan motivasi yang timbul dalam diri peserta didik sendiri, tanpa adanya pengaruh dari luar individu. ${ }^{4}$ Apabila mahasiswa yang telah memiliki motivasi internal dalam dirinya, maka secara sadar daya dorong seseorang individu sebagai kekuatan untuk melakukan aktivitas belajar yang berhubungan dengan kebutuhan. Jadi motivasi internal adalah modal utama bagi seorang peserta didik apabila ingin sukses.

Kedua, Motivasi Eksternal (Ekstrinsik Motivation). Motivasi eksternal adalah dorongan dari luar diri, tindakan atau perbuatan yang didasari oleh dorongan-dorongan yang bersumber dari luar pribadi seseorang (lingkungan) untuk melakukan sesuatu

${ }^{3}$ Uno, H. B. (2008). Teori Motivasi dan Pengukurannya: Analisis Di Bidang Pendidikan . Jakarta: Bumi Aksara, h. 29

4 Purwanto, N. (1991). Psikologi Pendidikan . Bandung: Remaja Rosdakarya, h. 34 karena adanya paksaan dari luar. ${ }^{5}$ Jenis motivasi ini timbul akibat pengaruh individu, apakah karena adanya ajakan, suruhan atau paksaan dari orang lain sehingga dengan kondisi yang demikian akhirnya seseorang mau melakukan sesuatu atau belajar. ${ }^{6}$ Misalnya, mahasiswa yang sedang menyelesaikan pekerjaan rumah, sekedar mematuhi perintah dosen, kalau tidak dipatuhi dosen akan memarahinya.

\subsubsection{Dasar-dasar Pemberian Motivasi \\ Salah satu tugas pokok yang} melekat pada diri seorang pendidik adalah sebagai motivator bagi peserta didik agar memiliki semangat dan kemauan untuk lebih giat dalam belajar. Petunjuk praktis yang perlu dilakukan oleh pendidik dalam membangkitkan motivasi peserta didik belajar di kelas, adalah: 1). Menjelaskan tujuan belajar kepada peserta didik. Pada permulaan belajar mengajar seharusnya terlebih dahulu pendidik menjelaskan mengenai Tujuan Instruksional Khusus (TIK) yang akan dicapai kepada mahasiswa. 2). Hadiah (Reward). Hal ini akan memacu semangat mereka untuk lebih belajar lebih giat lagi. 3). Saingan. Dosen berusaha mengadakan persaingan di antara peserta didik untuk meningkatkan prestasi

${ }^{5}$ Sudarsono. (1999). Kamus Filsafat dan Psikologi . Jakarta: Rineka Cipta, h. 32

${ }^{6}$ Hasan, C. (1994). Dimensi-Dimensi Psikologi Pendidikan. Surabaya: Al-Ikhlas, h. 35 
Peningkatan Motivasi dan Hasil Belajar Mahasiswa Pada Mata Kuliah Bahasa Arab Materi Hiwar dengan Menggunakan Metode Role Play Pada Program Studi

Pendidikan Agama Islam Semester II Universitas Muhammadiyah Sumatera Utara (Hasrian Rudi Setiawan)

belajarnya. 4). Pujian. Mahasiswa yang berprestasi sudah sepantasnya diberikan penghargaan. Tentunya pujian yang membangun. 5). Hukuman. Hukuman diberikan kepada mahasiswa yang berbuat kesalahan saat proses belajar mengajar. Hukuman ini diberikan degan harapan agar mahasiswa mau merubah diri dan berusaha memacu motivasi belajarnya. 6). Membangkitkan dorongan kepada peserta didik untuk belajar. Dengan cara memberikan perhatian secara maksimal kepada peserta didik. 7). Membentuk kebiasaan belajar yang baik. 8). Menggunakan metode yang bervariasi. 9). Membantu kesulitan belajar peserta didik secara individual maupun kelompok. 10). Menggunakan media yang baik dan sesuai dengan tujuan pembelajaran. ${ }^{7}$

\subsubsection{Peran dan Fungsi Motivasi dalam Proses Pembelajaran}

Kegiatan belajar sangat memerlukan motivasi, karena hasil belajar akan menjadi optimal, kalau ada motivasi. Magkin baik motivasi yang diberikan, maka akan semangkin berhasil pula pelajaran yang dipelajarinya. Dengan demikian motivasi merupakan suatu proses, yang menghantarkan peserta didik kepada pengalaman-pengalaman yang memungkinkan mereka dapat belajar. Adapun di antara peran motivasi dalam proses pembelajaran adalah: 1). Memberikan semangat dan

${ }^{7}$ Hamalik, O. (2003). Kurikulum dan Pembelajaran. Jakarta: Bumi Aksara, h. 53 mengaktifkan peserta didik agar tetap berminat. 2). Membantu memenuhi kebutuhan akan hasil jangka pendek dan hasil jangka panjang. 3). Membantu memusatkan perhatian peserta didik pada tugas-tugas tertentu yang berhubungan dengan pencapaian tujuan belajar. ${ }^{8}$

Sedangkan fungsi motivasi yang berkenaan dengan proses belajar mengajar, adalah: Pertama, Fungsi penggerak, yaitu penggerak atau pendorong untuk melakukan kegiatan belajar peserta didik, yang dapat dilakukan melalui berbagai cara, antara lain: 1). Motivasi kompetensi. Motivasi kompetensi menggerakkan tindakan-tidakan, seperti menyelidiki, memperhatikan, berbicara, penalaran, dan memanipulasi, 2). Metode penemuan. Metode ini dimaksudkan agar peserta didik memberi stimulan terhadap dirinya sendiri sehingga ia melakukan fungsi penggerak motivasinya, 3). Belajar terprogram. Kelompok belajar secara terbimbing berisi serangkaian pertanyaan dan jawaban, yang disusun secara bertahap sampai pada penyelesaian masalah. Cara belajar seperti ini, menuntut mahasiswa untuk membuat inferensi dan mengingat aturan-aturan tanpa bantuan atau penjelasan dari dosen, 4). Prosedur brainstorming. Prosedur ini dimaksudkan agar mahasiswa mampu memproduksi ide-ide yang baik,

${ }^{8}$ Daradjat, Z. (2008). Metodik Khusus Pengajaran Agama Islam. Jakarta: Bumi Aksara, h. 34 
melalui diskusi dan kritik. Istilah lain yang digunakan adalah prosedur urun pendapat. Beberapa keuntungan prosedur ini adalah menghasilkan ideide lebih banyak dibandingkan dengan cara lain, seperti pengarahan janji, ataupun hadiah. ${ }^{9}$

Kedua, Fungsi harapan, yaitu dosen memberikan harapan-harapan tersebut untuk menggugah motivasi belajar. Adapun cara-cara yang dapat dilakukan untuk memenuhi fungsi harapan ini antara lain: 1). Merumuskan tujuan intruksional sekhusus mungkin. Tujuan yang spesifik, operasional, dan dapat diamati agar lebih mendorong mahasiswa untuk mencapainya. Dalam hubungan ini telah terkandung harapan-harapan yang diinginkan mahasiswa, 2). Tujuan intruksional hendaknya terbagi menjadi tiga kategori, yaitu tujuan intruksional yang langsung, intermediate, dan jangka panjang. Jauh dekatnya tujuan intruksional memberikan pengaruh terhadap kepercayaan mahasiswa untuk mencapainya, 3). Perubahanperubahan harapan. Harapan adalah produk dari pengalaman masa lampau. Keberhasilan atau kegagalan pada masa lampau merupakan unsur utama untuk meramalkan keberhasilan dan kegagalan yang mungkin terjadi pada masa yang akan datang, 4). Tingkat aspirasi. Tingkat aspirasi dimaksudkan

9 Hamdani. (2010). Strategi Belajar Mengajar . Bandung: CV. Pustaka Setia, h. 31 sebagai pembangkit motivasi dengan berpedoman pada keberhasilan masa lalu yang mengkondisikan peserta didik untuk menambah harapanharapan mereka. Karena kegagalan masa lalu dapat menyebabkan mahasiswa, merendah harapannya. Hal ini dilakukan untuk menjaga agar kegagalan tidak terulang. ${ }^{10}$

\subsubsection{Metode Pendidik dalam Memotivasi Peserta Didik Untuk Belajar}

Pendidik memiliki peran yang sangat besar dalam memotivasi belajar peserta didik melalui berbagai aktivitas belajar yang didasarkan pada pengalaman dan kemampuan pendidik kepada peserta didik secara individual. Selain pendidik, orang tua, masyarakat dan teman juga sangat berperan aktif dalam menumbuhkan motivasi belajar peserta didik. Beberapa metode motivasi yang dapat dilakukan dalam pembelajaran, di antaranya:

1. Memberikan penghargaan dengan menggunakan kata-kata, seperti ucapan bagus sekali, hebat, menakjubkan, dan lain sebagainya.

2. Memberikan nilai ulangan sebagai pemacu bagi peserta didik untuk belajar lebih giat.

3. Mengadakan permainan dan menggunakan simulasi. Mengemas pembelajaran dengan menciptakan suasana yang menarik sehingga proses pembelajaran menjadi menyenangkan dan dapat melibatkan afektif dan

\footnotetext{
${ }^{10}$ Ibid, h. 36
} 
Peningkatan Motivasi dan Hasil Belajar Mahasiswa Pada Mata Kuliah Bahasa Arab Materi Hiwar dengan Menggunakan Metode Role Play Pada Program Studi

Pendidikan Agama Islam Semester II Universitas Muhammadiyah Sumatera Utara (Hasrian Rudi Setiawan)

pisikomotorik peserta didik. Proses pembelajaran yang menarik akan memudahkan peserta didik memahami apa yang disampaikan.

4. Menumbuhkan dan menimbulkan rasa ingin tahu dalam diri peserta didik. Rasa ingin tahu dapat ditimbulkan oleh suasana yang tibatiba atau mengejutkan.

5. Menumbukhan persaingan antara peserta didik, maksudnya pendidik memberikan kegiatan kepada peserta didik dalam setiap kegiatan, di mana peserta didik dalam melakukan tugasnya tidak bekerjasama dengan peserta didik yang lain. Dengan demikian peserta didik akan dapat membandingkan hasil pekerjaan yang dilakukannya dengan hasil peserta didik lainnya.

6. Memberikan contoh dan sikap yang positif, artinya dalam memberikan pekerjaan kepada peserta didik dosen tidak dibenarkan meninggalkan ruangan untuk melaksanakan pekerjaan yang lain.

7. Penampilan seorang pendidik, artinya penampilan seorang pendidik yang bersih, rapih, sopan, dan menarik akan memotivasi peserta didik dalam mengikuti pelajaran. Termasuk juga kepribadian pendidik, pendidik yang masuk kelas dengan wajah tersenyum akan membuat peserta didik senang mengikuti pelajaran yang sedang berlangsung. ${ }^{11}$

${ }^{11}$ Daradjat, Z. (2008). Metodik Khusus Pengajaran Agama Islam. Jakarta: Bumi Aksara, h. 26

\subsection{Hasil Belajar Mahasiswa}

\subsubsection{Pengertian Hasil Belajar}

Hasil belajar merupakan kemampuan-kemampuan yang dimiliki seorang mahasiswa setelah peserta didik menerima perlakukan dari dosen selaku pendidik. Sedangkan menurut Nana Sudjana, hasil belajar adalah kemampuan-kemampuan yang dimiliki mahasiswa setelah menerima pengalaman belajarnya. ${ }^{12}$ Dari definisi tersebut, dapat dipahami bahwa hasil belajar adalah merupakan hasil dan bukti belajar seseorang yang ditunjukkan dengan adanya perubahan tingkah laku. Hasil belajar akan tampak pada setiap perubahan pada aspek-aspek tersebut, baik dari salah satu aspek atau beberapa aspek. Adapun aspek-aspek tersebut adalah pengetahuan, pengertian, kebiasaan, keterampilan, emosional, hubungan soisal, budi pekerti dan sikap.

\subsubsection{Faktor-faktor Yang Mempengaruhi Hasil Belajar Mahasiswa}

Secara umum ada dua faktor yang mempengaruhi hasil belajar yang dicapai oleh mahasiswa, di antaranya adalah:

\section{Faktor Internal}

Dari sisi diri peserta didik, terdapat dua hal yang dapat

\footnotetext{
${ }^{12}$ Sudjana, N. (2005). Penilaian Hasil Proses Belajar Mengajar. Bandung: PT. Remaja Rosdakarya, h. 3
} 
mempengaruhi aktivitas dan hasil belajarnya, yaitu kondisi psikologis dan fisiologis. Kondisi psikologis adalah keadaan jiwa atau ruhaninya. Sedangkan kondisi fisiologis merupakan kondisi fisik, jasmani, atau tubuh peserta didik yang belajar. Dalam hal ini kondisi psikologis peserta didik sangat berpengaruh terhadap kegiatan belajar dan hasil yang akan dicapai. Seorang peserta didik yang kurang matang secara psikologis akan mengalami kesulitan dalam memahami materi-materi pelajaran yang bersifat abstrak. Demikian pula peserta didik yang mengalami gangguan atau jiwanya tidak stabil, maka akan sulit mencapai hasil yang baik dalam belajar.

Sama halnya dengan kondisi psikologis, kondisi fisiologis peserta didik juga akan sangat berpengaruh terhadap kegiatan belajar dan hasil yang akan dicapainya, seperti seorang peserta didik yang sedang terganggu kesehatan jasmani atau panca indranya, keadaan tersebut akan mengganggu terhadap kegiatan belajar dan hasil yang akan dicapai. Begitu pula keadaan peserta didik yang kurang gizi juga akan berpengaruh negatif terhadap aktivitas belajar dan hasil belajar yang dicapai. Kedua kondisi terebut menyebabkan fisik peserta didik menjadi lemah sehingga berpegaruh terhadap kemampuannya dalam memusatkan perhatian atau berkonsentrasi dalam belajar.

\section{Faktor Eksternal}

Faktor eksternal adalah segala sesuatu yang berasal dari luar diri peserta didik yang dapat mempengaruhi aktivitas dan hasil belajarnya. Ada dua faktor eksternal yang dapat mempengaruhi aktivitas dan hasil belajar seseorang peserta didik, yaitu:

a. Manusia atau yang disebut dengan faktor-faktor sosial. Misalnya ketika Ani sedang belajar, tiba-tiba di samping rumah ada sekumpulan anak yang ribut sambil bermain petasan. Kondisi tersebut mengakibatkan Ani mengalami gangguan dalam memusatkan perhatian atau berkonsentrasi dalam belajar. Karena itu Ani mengalami gangguan dalam belajar disebabkan faktor manusia atau faktor sosial.

b. Faktor non-manusia atau faktor non-sosial. Faktor ini menyangkut banyak hal, seperti keadaan suhu udara, keadaan cuaca, keadaan ruangan, sarana dan fasilitas.

\subsubsection{Penilaian Belajar}

Dalam membicarakan hasil belajar tidak bisa dipisahkan dari penilaian sebagai aktivitas di dalam menentukan tinggi rendahnya hasil belajar. Bila membicarakan penilaian maka tidak terlepas dari masalah evaluasi, sebab evaluasi merupakan suatu tindakan untuk menentukan nilai segala sesuatu di dalam pembelajaran. Evaluasi hasil belajar adalah suatu proses yang sistematis dan berkelanjutan untuk menentukan 
Peningkatan Motivasi dan Hasil Belajar Mahasiswa Pada Mata Kuliah Bahasa Arab Materi Hiwar dengan Menggunakan Metode Role Play Pada Program Studi

Pendidikan Agama Islam Semester II Universitas Muhammadiyah Sumatera Utara (Hasrian Rudi Setiawan)

kualitas daripada sesuatu, berdasarkan pertimbangan dan kriteria tertentu untuk membuat suatu keputusan. ${ }^{13}$

Dari keterangan di atas, dapat dipahami bahwa untuk melihat hasil belajar mahasiswa meningkat atau tidak, maka dosen hendaknya melakukan evaluasi terhadap hasil belajar mahasiswa. Karena itu, evaluasi memiliki manfaat di antaranya: 1). Untuk mengetahui tingkat penguasaan peserta didik terhadap materi yang telah diberikan, 2). Untuk mengetahui tingkat kemajuan dan kesesuaian hasil belajar peserta didik dengan standar kompetensi dan kompetensi dasar yang telah ditetapkan, 3). Untuk mengetahui kecakapan, motivasi, bakat, minat, dan sikap peserta didik terhadap program pembelajaran, 4). Untuk seleksi, yaitu memilih dan menentukan peserta didik yang sesuai dengan jenis pendidikan tertentu, 5). Untuk menentukan kenaikan kelas, 6). Untuk mendiagnosis keunggulan dan kelemahan peserta didik dalam mengikuti kegiatan pembelajaran. Keunggulan peserta didik dapat dijadikan dasar bagi pendidik untuk memberikan pembinaan dan pengembangan lebih lanjut, sedangkan kelemahannya dapat dijadikan acuan untuk memberikan bantuan atau bimbingan, 7). Untuk menempatkan

13 Arifin, Z. (2012). Evaluasi Pembelajaran. Jakarta: Direktorat Jendral Pendidikan Islam Kementrian Agama, h. 23 peserta didik sesuai dengan potensi yang dimilikinya. ${ }^{14}$

$$
\text { Dari beberapa manfaat }
$$
evaluasi di atas, dapat diketahui bahwa evaluasi hasil belajar adalah memberikan pelayanan atas proses pembelajaran, evaluasi sangat penting dilakukan untuk memutuskan tujuan setiap usaha. Dalam pelaksanaan evaluasi, secara umum tes hasil belajar dapat dibedakan menjadi dua macam, yaitu:

a. Tes formatif adalah tes yang diadakan sebelum atau selama pelajaran berlangsung. Tes formatif ini mempunyai dua tujuan, yaitu untuk membantu dosen dalam membuat perencanaan dan untuk membantu mahasiswa mengenali segi-segi yang perlu ditanggani. Tes ini disebut juga pra tes. Adapun manfaat dari tes formatif adalah untuk membantu dosen menentukan apa yang sudah diketahui mahasiswa. Kadang juga tes formatif dimanfaatkan untuk mengetahui segi-segi apa yang masih lemah ketika pengajaran sudah selesai. ${ }^{15}$

b. Tes sumatif adalah tes yang diselenggarakan pada akhir seluruh kegiatan belajar mengajar. Tujuannya adalah untuk memberi tahu dosen dan mahasiswa tentang seberapa jauh yang telah dicapai

\footnotetext{
14 Iskandar. (2009). Psikologi Pendidikan Sebuah Orientasi Baru, h. 46.

${ }^{15}$ Purwanto, M. N. (1994). PrinsipPrinsip dan Teknik Evaluasi Pengajaran. Bandung: Rosdakarya, h. 25.
} 
selama satu triwulan dan selama satu semester. ${ }^{16}$

\subsection{Metode Role Play}

\subsubsection{Pengertian Metode Role Play}

Metode role playing adalah cara penguasaan bahan-bahan pelajaran melalui pengembangan imajinasi dan penghayatan mahasiswa. Pengembangan imajinasi dan penghayatan dilakukan mahasiswa dengan memerankannya sebagai tokoh hidup atau benda mati. permainan ini pada umumnya dilakukan lebih dari satu orang, bergantung pada apa yang diperankan. ${ }^{17}$

\begin{tabular}{lcr}
\multicolumn{3}{c}{ Kelebihan metode ini yaitu } \\
seluruh & mahasiswa & dapat \\
berpartisipasi & dan mempunyai \\
kesempatan & untuk & menguji \\
kemampuannya dalam bekerja sama. & \\
Dalam metode ini ada beberapa
\end{tabular}
keuntungan di antaranya adalah: 1). Mahasiswa bebas mengambil keputusan dan berekspresi secara utuh, 2). Permainan adalah penemuan yang mudah dan dapat digunakan dalam situasi dan waktu yang berbeda, 3). Dosen dapat mengevaluasi pemahaman setiap mahasiswa melalui pengamatan pada saat melakukan permainan, 4). Permainan merupakan

\footnotetext{
16 Rosnita. (2007). Evaluasi Pendidikan. Bandung: Ciptapustaka Media, h. 27.

17 Winataputra. (2005).

Perkembangan Peserta Didik. Jakarta: Universitas Terbuka Depdiknas, h. 43.
}

pengalaman yang menyenangkan bagi mahasiswa. $^{18}$

\subsubsection{Langkah}

Pelaksanaan

\section{Metode Role Play}

Langkah-langkah

melaksanakan metode role play terdiri dari beberapa tahapan, di antaranya adalah: Pertama, tahap pendahuluan yaitu menetapkan topik atau masalah serta tujuan yang hendak dicapai tentang materi, dosen memberikan gambaran masalah dalam situasi yang akan diperankan, dosen menetapkan pemain yang akan terlibat dalam role playing, peranan yang harus dimainkan oleh para pemeran serta waktu yang disediakan, dosen memberikan kesempatan kepada mahasiswa untuk bertanya khususnya pada mahasiswa yang terlibat dalam pemeranan. Kedua, tahap pelaksanaan yaitu dosen mempersilahkan kelompok role playing yang telah ditunjuk untuk tampil sementara mahasiswa yang tidak tampil melaksanakan observasi. Selain mahasiswa lain sebagai pengamat, dosen juga mengamati kegiatan role playing untuk memantau jalannya kegiatan dan mengecek pelaksanaan observasi yang dilakukan mahasiswa.

Ketiga, tahap penutup yaitu dosen melakukan diskusi baik tentang jalannya simulasi maupun materi cerita yang disimulasikan, dosen harus mendorong agar mahasiswa dapat

\footnotetext{
${ }^{18}$ Hamdani. (2010). Strategi Belajar Mengajar . Bandung: CV. Pustaka Setia, h. 67
} 
Peningkatan Motivasi dan Hasil Belajar Mahasiswa Pada Mata Kuliah Bahasa Arab Materi Hiwar dengan Menggunakan Metode Role Play Pada Program Studi

Pendidikan Agama Islam Semester II Universitas Muhammadiyah Sumatera Utara (Hasrian Rudi Setiawan)

memberikan kritik dan tanggapan terhadap proses pelaksanaan simulasi. Selama proses pembelajaran dosen memberikan penilaian kepada mahasiswa, baik dalam penguasaan materi, keaktifan dan penampilan mahasiswa dalam bermain peran. Sebagai kegiatan akhir mahasiswa diberi kesempatan untuk menanyakan hal-hal yang belum jelas dan mencatat hal-hal yang penting dari materi yang telah dipelajari. Selanjutnya siswa melaksanakan evaluasi tertulis. ${ }^{19}$

\subsection{Hipotesis Tindakan}

Adapun hipotesis tindakan dalam penelitian ini, yaitu: Dengan menggunakan metode role play akan dapat meningkatkan motivasi dan hasil belajar mahasiswa dalam mata kuliah bahasa Arab pada materi hiwar.

\section{Metode Penelitian}

\subsection{Tempat dan Waktu Penelitian}

$\begin{array}{llr}\text { Penelitian } & \text { ini dilaksanakan } \\ \text { pada } & \text { Program Studi Pendidikan }\end{array}$
Agama Islam Universitas Muhammadiyah Sumatera Utara pada mata kuliah bahasa Arab yang dikhususkan pada materi hiwar. Penelitian ini dilaksanakan pada semester II antara bulan Januari 2015 sampai April 2015.

\subsection{Subjek Penelitian}

Adapun yang menjadi subjek penelitian dalam penelitian tindakan

\begin{tabular}{lll}
\hline 19 Uno, H. B. (2010). & Model \\
Pembelajaran: Menciptakan & Proses \\
Belajar Yang Efektif dan Kreatif. Jakarta: \\
Bumi Aksara, h. 64
\end{tabular}

kelas ini adalah mahasiswa semester II Program Studi Pendidikan Agama Islam UMSU yang berjumlah 36 orang, terdiri dari 8 orang laki-laki dan 28 orang perempuan di Program Studi Pendidikan Agama Islam Fakultas Agama Islam UMSU.

\subsection{Prosedur Penelitian}

Prosedur penelitian tindakan yang ditempuh merupakan suatu siklus yang mencakup empat tahap, yaitu perencanaan, pelaksanaan tindakan, observasi, dan evaluasi refleksi. Adapun prosedur penelitian tersebut dapat dilihat pada gambar di bawah ini:

\section{Gambar I: Siklus Penelitian Tindakan Kelas (PTK)}

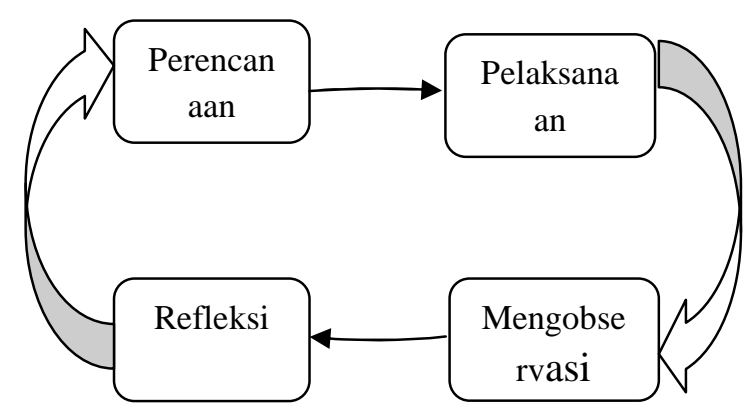

\subsection{Instrumen Penggumpulan Data}

Metode pengumpulan data adalah mengamati variabel yang diteliti dengan menggunakan metode tertentu. ${ }^{20}$ Metode pengumpulan data dalam penelitian ini adalah:

1. Tes, digunakan untuk mendapatkan data mengenai hasil belajar mahasiswa.

2. Dokumentasi, digunakan dalam penelitian ini adalah nilai ujian

20 Arikunto, S. (2002). Prosedur

Penelitian. Jakarta: PT. Rineka Cipta, h. 42 
mata kuliah bahasa Arab mahasiswa semester ganjil Program Studi Pendidikan Agama Islam UMSU. Metode dokumentasi dalam penelitian ini digunakan untuk mengetahui kondisi awal mahasiswa

3. Observasi, digunakan untuk mengumpulkan data tentang aktivitas mahasiswa dalam proses pembelajaran dengan menggunakan metode role play.

\subsection{Teknik Analisis Data}

Analisis data adalah proses pengorganisasian data ke dalam pola, kategori dan satuan uraian dasar, sehingga dapat ditemukan tema seperti yang disarankan oleh data. ${ }^{21}$ Dalam pelaksanaan penelitian tindakan kelas ini terdapat dua jenis data yang dapat dikumpulkan oleh peneliti, yaitu data kualitatif dan data kuantitatif.

Adapun teknik analisis data yang digunakan dalam penelitian ini yaitu analisis deskriptif. Dalam analisis deskriptif, ada tiga alur kegiatan yang menjadi satu kesatuan yang tidak dapat terpisahkan, yaitu: Pertama, reduksi data yaitu, pada teknik ini peneliti melakukan proses pemilahan data yang relevan, penting dan bermakna mulai dari awal pengumpulan data hingga peneliti melakukan penyusunan laporan penelitian. Kedua, penyajian data

\footnotetext{
${ }^{21}$ Moleong, L. J. (1995). Metodologi Penelitian Kualitatif. Bandung: PT. Remaja Rosdakarya, h. 74
}

yaitu, teknik ini memaparkan hasil temuan secara narasi. Penyajian data dilakukan dalam rangka pengorganisasian hasil reduksi dengan cara menyusun secara naratif sekumpulan informasi yang telah diperoleh dari hasil reduksi, sehingga data dapat disimpulkan dan selanjutnya dapat diberikan tindakan. Ketiga, penarikan kesimpulan yaitu, memberikan kesimpulan terhadap hasil penafsiran dan evaluasi. Kegiatan ini mencakup pencarian makna data dan memberi pejelasaan. Selanjutnya kemudian dilakukan verifikasi, yaitu pengujian kebenaran, kekokohan dan mencocokkan maknamakna yang muncul dari data. ${ }^{22}$

$$
\text { Selanjutnya data hasil }
$$
penelitian tersebut akan dianalisis sebagai berikut:

1. Hasil observasi terhadap aktivitas pembelajaran mahasiswa selama kegiatan pembelajaran dengan menggunakan metode role play dan respon mahasiswa terhadap pelaksanaan pembelajaran dianalisis secara deskriptif dan data kuantitatif menggunakan persentase.

2. Hasil belajar peserta didik dianalisis dengan menggunakan prinsip konversi lima, yaitu:

$$
\begin{array}{ll}
93-100 & =\text { Sangat Tinggi } \\
84-92 & =\text { Tinggi } \\
75-83 & =\text { Sedang } \\
74-70 & =\text { Cukup } \\
& \\
{ }^{22} \text { Huberman, } & \text { M. B. (1992). Analisis }
\end{array}
$$
Data Kualitatif. Jakarta: UI Press, h. 72 
Peningkatan Motivasi dan Hasil Belajar Mahasiswa Pada Mata Kuliah Bahasa Arab Materi Hiwar dengan Menggunakan Metode Role Play Pada Program Studi

Pendidikan Agama Islam Semester II Universitas Muhammadiyah Sumatera Utara (Hasrian Rudi Setiawan)

0-69 = Rendah

Kriteria ideal ketuntasan belajar minimal yang ditetapkan Program Studi Pendidikan Agama Islam Universitas Muhammadiyah Sumatera Utara mata kuliah bahasa Arab adalah 75 sedangkan ketuntasan klasikal tercapai bila terdapat $85 \%$ mahasiswa yang tuntas belajar. Analisis data dalam penelitian ini menggunakan analisis deskriptif, sesuai dengan datanya:

1. Hasil belajar dianalisis dengan analisis deskriptif yaitu membandingkan hasil belajar (nilai tes) antara siklus dan mencari nilai rata-rata atau persentase hasil belajar.

2. Observasi dianalisis dengan analisis deskriptif dan reflektif berdasarkan hasil observasi dan refleksi berkaitan pada tingkat respon dan aktifitas belajar mahasiswa.

\section{Hasil dan Pembahasan Penelitian}

\subsection{Hasil Penelitian}

\subsubsection{Deskripsi Hasil Penelitian Pra Tindakan}

Jumlah mahasiswa Program

Studi Pendidikan Agama Islam Fakultas Agama Islam UMSU pada semester ganjil yang lalu berjumlah 40 orang mahasiswa, namun pada semester genap ini jumlah mahasiswa Program Studi Pendidikan Agama Islam Fakultas Agama Islam UMSU berkurang menjadi 36 orang, hal ini di karenakan mahaswa yang empat orang tersebut adalah mahasiswa pengambilan ke bawah.

Setelah dilakukan kegiatan perkuliahan pada mata kuliah bahasa Arab materi hiwar di Program Studi Pendidikan Agama Islam Fakultas Agama Islam UMSU dalam kegiatan pra tindakan, maka untuk menguji pengetahuan awal mahasiswa maka peneliti terlebih dahulu melaksanakan tes dengan mengujikan 10 soal pilihan ganda kepada mahasiswa mengenai materi hiwar.Dari hasil evaluasi tersebut maka diperoleh hasil belajar dari evaluasi yang dilakukan sebagaimana dalam tabel berikut:

Hasil Belajar Pra Tindakan

\begin{tabular}{|c|c|c|c|}
\hline No & Nilai & $\mathbf{F}$ & $\%$ \\
\hline 1 & 100 & 0 & 0.0 \\
\hline 2 & 95 & 0 & 0.0 \\
\hline 3 & 90 & 3 & 8.3 \\
\hline 4 & 85 & 3 & 8.3 \\
\hline 5 & 80 & 2 & 5.6 \\
\hline 6 & 75 & 5 & 13.9 \\
\hline 7 & 70 & 7 & 19.4 \\
\hline 8 & 65 & 7 & 19.4 \\
\hline 9 & 60 & 4 & 11.1 \\
\hline 10 & 55 & 2 & 5.6 \\
\hline 11 & 50 & 3 & 8.3 \\
\hline \multicolumn{2}{|c|}{ Jumlah } & 36 & 100.00 \\
\hline
\end{tabular}

Berdasarkan tabel di atas, hasil perkuliahan mahasiswa dalam mata kuliah Bahasa Arab pada materi hiwar dalam penelitian tahap pra tindakan menunjukkan bahwa hanya 13 orang yang tuntas atau $(36,1 \%)$, dengan kriteria ketuntasan minimal yaitu nilai 75 , berarti belum memiliki ketuntasan klasikal, karena ketuntasan klasikal 
baru tercapai apabila $85 \%$ mencapai nilai 75. Dilihat dari kategori nilai, maka hasil belajar pra tindakan ini tidak terdapat mahasiswa yang memiliki nilai dalam kategori sangat tinggi (93-100), mahasiswa yang memiliki kategori nilai tinggi (84-92) hanya 6 orang mahasiswa, 7 orang mahasiswa memiliki kategori nilai sedang (75-83), dan 7 orang siswa memiliki kategori nilai cukup (74-70).

Kemudian dari hasil lembar observasi pada penelitian tahap pra tindakan atas kegiatan perkuliahan mahasiswa ketika dosen mengajarkan materi pokok hiwar, dapat diketahui bahwa motivasi belajar mahasiswa dipaparkan sebagaimana dalam tabel berikut:

\section{Motivasi Belajar Siswa Pada} Pra Tindakan

\begin{tabular}{|c|c|c|c|}
\hline No & $\begin{array}{c}\text { Aspek Yang } \\
\text { Diamati }\end{array}$ & $\bar{F}$ & $\%$ \\
\hline 1 & Minat & 136 & 27.04 \\
\hline 2 & Perhatian & 124 & 24.65 \\
\hline 3 & Partisipasi & 126 & 25.05 \\
\hline 4 & Presentasi & 117 & 23.26 \\
\hline \multicolumn{2}{|r|}{ Jumlah } & 503 & 100.00 \\
\hline
\end{tabular}

Dari data uraian pada tabel di atas, maka motivasi belajar mahasiswa pada pra tindakan yang paling tinggi adalah aspek minat, yaitu 27,04\%, dan yang terendah adalah presentasi, yaitu 23,26\%. Namun secara umum presentase aspek yang ada dalam motivasi berada pada angka, yaitu $69,86 \%$. Artinya bahwa motivasi belajar mahasiswa, tergolong rendah dengan menggunakan metode ceramah dan tanya jawab.

Untuk memecahkan masalah rendahnya hasil belajar mahasiswa dan untuk meningkatkan motivasi belajar mahasiswa pada Program Studi Pendidikan Agama Islam Fakultas Agama Islam UMSU, maka diupayakan dengan menggunakan metode Role Play.

\subsubsection{Deskripsi Hasil Penelitian Siklus I}

a. Perencanaan (tahap persiapan)

Sebelum pelaksanaan siklus I, peneliti mengadakan pertemuan dengan dosen bahasa Arab yang mengajar di Program Studi Pendidikan Agama Islam Fakultas Agama Islam UMSU, untuk mendiskusikan beberapa masalah termasuk motivasi, hasil belajar mahasiswa, dalam mengikuti proses pembelajaran bahasa arab berdasarkan kegiatan pra tindakan yang telah dilakukan sebelumnya. Berdasarkan diskusi tersebut disimpulkanlah bahwa ada beberapa kendala dalam proses pembelajaran, yakni:

1) Sulitnya mahasiswa memahami materi pembelajaran yang disampaikan oleh dosen.

2) Masih banyak mahasiswa yang tidak serius mengikuti pembelajaran, karena kegiatan mahasiswa lebih banyak mendengarkan penjelasan dari dosen dibandingkan dengan mahasiswa melakukan pembelajaran/perkuliahan aktif. 
Peningkatan Motivasi dan Hasil Belajar Mahasiswa Pada Mata Kuliah Bahasa Arab Materi Hiwar dengan Menggunakan Metode Role Play Pada Program Studi

Pendidikan Agama Islam Semester II Universitas Muhammadiyah Sumatera Utara (Hasrian Rudi Setiawan)

3) Tidak berminatnya mahasiswa dalam mengikuti pembelajaran bahasa arab, disebabkan kegiatan pembelajaran bersifat monoton dengan mempergunakan metode ceramah.

4) Sulitnya mahasiswa memahami dan mempraktekkan komunikasi dengan menggunakan bahasa Arab.

Dengan mengkaji kondisi proses pembelajaran yang terjadi, serta rendahnya motivasi dan hasil belajar mahasiswa. Untuk memperbaiki kelemahan tersebut, maka pada pelaksanaan siklus I dibuat perencanaan yaitu:

1) Menyusun Satuan Acara Perkuliahan SAP Bahasa Arab dengan menerapkan metode Role Play.

2) Mempersiapkan materi ajar, dengan materi hiwar.

3) Menyiapkan media pelajaran yang tepat yang mendukung terhadap pelaksanaan pembelajaran.

4) Menyiapakan lembar kegiatan peserta didik.

5) Menyusun instumen penelitian:

a) Perangkat soal evaluasi hasil belajar mahasiswa.

b) Lembar observasi aktivitas siswa, yang bertujuan untuk melihat keadaan aktivitas mahasiswa dalam proses pembelajaran di kelas.

\section{b. Pelaksanaan Tindakan Siklus I}

Pelaksanaan tindakan siklus I dilaksanakan pada hari Selasa tanggal 21 Februari 2015, peneliti memulai siklus I pada pengenalan tentang materi hiwar, dengan menerapkan metode Role Play. Siklus I ini dilakukan selama dua SKS. Kegiatan pembelajaran dilakukan sebagai berikut:

1) Kegiatan pendahuluan

a) Dosen membimbing mahasiswa untuk memulai pembelajaran dengan membaca basmalah. Melakukan apersepsi yaitu mengarahkan kesiapan peserta didik untuk mengikuti pembelajaran kemudian memberikan motivasi dan informasi kompetensi yang akan dicapai oleh siswa.

b) Dosen menjelaskan judul materi perkuliahan, yaitu materi hiwar.

c) Menyebutkan standar kompetensi materi yang akan diajarkan

d) Dosen menjelaskan indikator pencapaian keberhasilan pembelajaran yang ingin dicapai, yaitu menjelaskan pengertian hiwar dalam bahasa Arab, kemudian menjelaskan bagaimana melakukan hiwar (percakapan) dalam bahasa Arab yang baik.

2) Kegiatan inti

a) Dosen mempresentasikan dan mendemontrasikan materi hiwar kepada mahasiswa.

b) Dosen menyajikan media audio visual yang isinya tentang peragaan (pelaksanaan) tentang materi hiwar (percakapan).

3) Kegiatan penutup 
a) Proses pembelajaran ditutup dengan membuat rangkuman pelajaran.

b) Dosen menanyakan kepada beberapa orang mahasiswa tentang refleksi perkuliahan yang telah dilakukan atau post tes.

c) Dosen membimbing mahasiswa untuk menutup pembelajaran dengan membaca hamdalah dan mengakhiri pembelajaran dengan mengucapkan salam.

Pada pertemuan kedua, kegiatan pembelajaran dilakukan sebagai berikut:

1) Kegiatan pendahuluan

a) Dosen membimbing peserta didik untuk memulai pembelajaran dengan membaca basmalah serta melakukan apersepsi.

b) Mempersiapkan perlengkapan sebagai fasilitas dalam melakukan pembelajaran dengan metode role play pada materi hiwar.

2) Kegiatan inti

a) Dosen meminta beberapa kelompok mahasiswa untuk melakukan peragaan percakapan didepan kelas dengan menggunakan bahasa Arab dengan menggunakan metode role play.

b) Kemudian dosen meminta kelompok yang lain untuk mengkomentari kelompok mahasiswa yang lain dalam memerankan pembelajaran bahasa Arab dengan metode Role Play tersebut. Dosen meluruskan hasil praktek siswa yang kurang tepat.

c) Kemudian dosen memperbaiki kata-kata yang kurang tepat/ salah pada mahasiswa pada materi hiwar dengan menggunakan metode role play tersebut.

3) Kegiatan penutup

a) Melakukan evaluasi (evaluasi pengetahuan siswa)

b) Dosen membimbing mahasiswa untuk menutup perkuliahan dengan membaca hamdalah dan mengakhiri perkuliahan dengan mengucapkan salam.

\section{c) Hasil Observasi Siklus I}

Berdasarkan hasil observasi peneliti terhadap pelaksanaan perkuliahan bahasa Arab pada materi hiwar denagn menggunakan metode Role Play, dapat diketahui bahwa:

\section{1) Motivasi Belajar Mahasiswa \\ Pada Siklus I}

Berdasarkan hasil penelitian pada siklus I, maka motivasi belajar mahasiswa pada mata kuliah bahasa Arab materi hiwar dapat dilihat pada tabel, yaitu:

\section{Motivasi Belajar Siswa Pada Siklus I}

\begin{tabular}{|c|c|c|c|}
\hline No & $\begin{array}{c}\text { Aspek Yang } \\
\text { Diamati }\end{array}$ & $\mathrm{F}$ & $\%$ \\
\hline 1 & Minat & 151 & 25.95 \\
\hline 2 & Perhatian & 152 & 26.12 \\
\hline 3 & Partisipasi & 143 & 24.57 \\
\hline 4 & Presentasi & 136 & 23.37 \\
\hline
\end{tabular}


Peningkatan Motivasi dan Hasil Belajar Mahasiswa Pada Mata Kuliah Bahasa Arab Materi Hiwar dengan Menggunakan Metode Role Play Pada Program Studi

Pendidikan Agama Islam Semester II Universitas Muhammadiyah Sumatera Utara (Hasrian Rudi Setiawan)

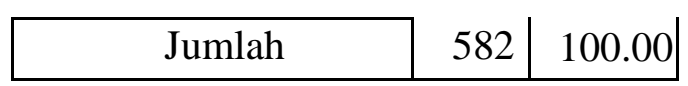

Dari keterangan tabel di atas, maka dapat dilihat motivasi belajar mahasiswa pada siklus I diungkapkan yang paling tinggi adalah aspek pengetahuan mencapai $26,12 \%$, dan yang terendah adalah aspek presentasi, yaitu $23,37 \%$. Namun secara umum presentase aspek yang ada dalam motivasi belajar pada siklus I mengalami peningkatan dari kegiatan pra tindakan, yaitu mencapai $80,83 \%$. Itu artinya motivasi mahasiswa dalam matakuliah bahasa Arab materi hiwar dengan menggunakan metode role play, mengalami peningkatan, meskipun perlu dimaksimalkan dalam siklus II.

\section{2) Hasil Belajar Mahasiswa}

Siklus I dianggap sukses atau efektif apabila mahasiswa mendapat nilai $\geq 75$, atau secara klasikal $85 \%$ mahasiswa tuntas dalam perkuliahan. Dari tindakan yang sudah dilaksanakan pada siklus I, pada akhir pembelajaran diberi tes hasil belajar. Hasil pembelajaran mahasiswa yang telah mendapat perlakuan pembelajaran dengan menggunakan metode role play pada siklus I, dapat dilihat pada tabel berikut:

\section{Hasil Belajar Siswa Siklus I}

\begin{tabular}{|c|c|c|c|}
\hline No & Nilai & $\mathbf{F}$ & $\mathbf{\%}$ \\
\hline 1 & 100 & 0 & 0.0 \\
\hline 2 & 95 & 3 & 8.3 \\
\hline 3 & 90 & 2 & 5.6 \\
\hline
\end{tabular}

\begin{tabular}{|c|c|c|c|}
\hline 4 & 85 & 2 & 5.6 \\
\hline 5 & 80 & 9 & 25.0 \\
\hline 6 & 75 & 7 & 19.4 \\
\hline 7 & 70 & 9 & 25.0 \\
\hline 8 & 65 & 2 & 5.6 \\
\hline 9 & 60 & 1 & 2.8 \\
\hline 10 & 55 & 1 & 2.8 \\
\hline 11 & 50 & 0 & 0.0 \\
\hline \multicolumn{2}{|c|}{ Jumlah } & 36 & 100.00 \\
\hline
\end{tabular}

Berdasarkan tabel di atas, dapat diketahui bahwa hasil belajar mahasiswa dalam mata kuliah bahasa Arab materi hiwar pada siklus I menunjukkan bahwa hanya 23 orang yang tuntas atau $(63,89 \%)$. Pada siklus I ini, hasil belajar mahasiswa pada dasarnya mengalami peningkatan, dibandingkan dengan hasil yang didapat pada tahap pra tindakan, yaitu melalui pelaksanaan pembelajaran dengan menggunakan metode role play. Namun demikian perlu dimaksimalkan pada pelaksanaan siklus II.

\section{3) Refleksi Hasil Tindakan Siklus I}

Refleksi ini dilakukan untuk menentukan apakah tindakan siklus I harus diulangi atau telah mencapai tingkat keberhasilan. Dalam pelaksanaan kegiatan belajar mengajar diperoleh informasi dari hasil pengamatan adalah:

a. Berdasarkan hasil yang diperoleh dari observasi, bahwa motivasi mahasiswa pada siklus I meningkat. Peningkatan motivasi belajar mahasiswa tersebut, yaitu 
pada aspek minat mahasiswa dalam belajar mencapai $24,82 \%$, kemudian pada aspek perhatian mahasiswa terhadap penjelasan dosen mencapai 26,77 \%, sedangkan pada aspek presentasi mencapai $23,84 \%$ dan pada aspek partisipasi mahasiswa dalam pembelajaran mencapai $24,54 \%$. Namun secara umum keberhasilan dalam motivasi belajar pada siklus I mengalami peningkatan dari kegiatan pra tindakan, yaitu mencapai $81,48 \%$. Itu artinya motivasi mahasiswa dalam pendidikan agama Islam pada materi hiwar dengan menggunakan metode role play, mengalami peningkatan, meskipun perlu dimaksimalkan dalam siklus II.

b. Berdasarkan hasil tes akhir pada siklus I diperoleh data bahwa mahasiswa yang mendapat nilai tuntas hanya 31 orang mahasiswa atau (70,45 \%), dengan demikian kriteria keberhasilan pembelajaran belum mencapai kriteria yang maksimal sebagaimana telah ditetapkan pada siklus I. Karena ketuntasan klasikal baru tercapai apabila $85 \%$ mencapai nilai KKM, yaitu nilai 75 .

Dari uraian dan analisis data di atas, peneliti dapat menyimpulkan bahwa pembelajaran pada tindakan siklus I belum mencapai kriteria yang telah ditentukan yaitu persentase ketuntasan hasil belajar dan motivasi siswa untuk belajar dengan metode role play belum mencapai ketuntasan. Berdasarkan hasil refleksi tersebut maka perlu dilanjutkan pada tindakan siklus ke II.

\subsubsection{Deskripsi Hasil Penelitian Siklus II}

\section{a. Perencanaan (tahap persiapan)}

Untuk mengatasi berbagai kendala-kendala yang ditemukan di lapangan pada pelaksanaan pada siklus I dan setelah di refleksi maka pada kegiatan ini, ada beberapa hal yang harus dilakukan peneliti, yaitu:

1) Menyiapkan Satuan Acara Perkuliahan (SAP).

2) Menyiapkan materi pembelajaran tentang hiwar.

3) Menyiapkan soal-soal tes akhir tindakan.

4) Menyiapkan lembar kerja siswa.

5) Menyiapkan media pembelajaran bahasa Arab yang berkaitan dengan materi hiwar.

\section{b. Pelaksanaan Tindakan Siklus II}

Siklus II dimulai pada hari Senin, tanggal 03 Februari 2015. Siklus 2 juga dilaksanakan selama 2 kali pertemuan. Dikarenakan pada siklus I peneliti masih belum mampu mengelola waktu secara baik, maka pada siklus 2 ini peneliti melakukan perbaikan pada langkah-langkah pembelajaran pada Satuan Acara Perkuliahan (SAP). Adapun kegiatan pembelajaran yang dilakukan pada pertemuan pertama adalah:

1) Kegiatan pendahuluan 
Peningkatan Motivasi dan Hasil Belajar Mahasiswa Pada Mata Kuliah Bahasa Arab Materi Hiwar dengan Menggunakan Metode Role Play Pada Program Studi

Pendidikan Agama Islam Semester II Universitas Muhammadiyah Sumatera Utara (Hasrian Rudi Setiawan)

a) Dosen membimbing mahasiswa untuk memulai pembelajaran dengan membaca basmalah serta melakukan apersepsi yaitu mengarahkan kesiapan peserta didik untuk mengikuti pembelajaran kemudian memberikan motivasi dan informasi kompetensi yang akan dicapai.

b) Dosen menjelaskan judul pembelajaran, yaitu pelaksanaan hiwar.

c) Dosen menjelaskan indikator pencapaian keberhasilan perkuliahan yang ingin dicapai.

2) Kegiatan inti

a) Dosen mempresentasikan dan mendemontrasikan materi hiwar kepada mahasiswa.

b) Dosen menyajikan media audio visual yang isinya tentang peragaan (pelaksanaan) tentang materi hiwar (percakapan).

3) Kegiatan penutup

a) Proses pembelajaran ditutup dengan membuat rangkuman pelajaran.

b) Dosen menanyakan kepada beberapa orang mahasiswa tentang refleksi perkuliahan yang telah dilakukan atau post tes.

c) Dosen membimbing mahasiswa untuk menutup pembelajaran dengan membaca hamdalah dan mengakhiri pembelajaran dengan mengucapkan salam.
Pada pertemuan kedua, kegiatan pembelajaran dilakukan sebagai berikut:

1) Kegiatan pendahuluan

a) Dosen membimbing peserta didik untuk memulai pembelajaran dengan membaca basmalah serta melakukan apersepsi.

b) Mempersiapkan perlengkapan sebagai fasilitas dalam melakukan pembelajaran dengan metode role play pada materi hiwar.

2) Kegiatan inti

a) Dosen meminta beberapa kelompok mahasiswa untuk melakukan peragaan percakapan didepan kelas dengan menggunakan bahasa Arab dengan menggunakan metode role play.

b) Kemudian dosen meminta kelompok yang lain untuk mengkomentari kelompok mahasiswa yang lain dalam memerankan pembelajaran bahasa Arab dengan metode Role Play tersebut. Dosen meluruskan hasil praktek siswa yang kurang tepat.

c) Kemudian dosen memperbaiki kata-kata yang kurang tepat/ salah pada mahasiswa pada materi hiwar dengan menggunakan metode role play tersebut.

3) Kegiatan penutup

a) Melakukan evaluasi (evaluasi pengetahuan siswa) 
b) Dosen membimbing mahasiswa untuk menutup perkuliahan dengan membaca hamdalah dan mengakhiri perkuliahan dengan mengucapkan salam.

\section{c. Hasil Observasi Siklus II}

\section{1) Motivasi Belajar Mahasiswa}

\section{Pada Siklus II}

Berdasarkan hasil penelitian peneliti, maka hasil motivasi belajar mahasiswa pada mata kuliah bahasa Arab pada materi hiwar dapat dilihat pada tabel, yaitu:

Motivasi Belajar Mahasiswa Pada Siklus II

\begin{tabular}{|r|c|r|r|}
\hline No & $\begin{array}{c}\text { Aspek Yang } \\
\text { Diamati }\end{array}$ & F & \% \\
\hline 1 & Minat & 158 & 25.53 \\
\hline 2 & Perhatian & 159 & 25.69 \\
\hline 3 & Partisipasi & 155 & 25.04 \\
\hline 4 & Presentasi & 147 & 23.75 \\
\hline & Jumlah & 619 & 100.00 \\
\hline
\end{tabular}

Dari keterangan data tabel di atas, maka dapat dilihat motivasi belajar mahasiswa pada siklus II diungkapkan yang paling tinggi adalah aspek Perhatian mencapai 25,69\% dan yang terendah adalah aspek presentasi, yaitu $23,75 \%$. Namun secara umum presentase aspek yang ada dalam motivasi belajar pada siklus II mengalami peningkatan dari kegiatan pra tindakan dan siklus I, yaitu mencapai $85.97 \%$. Namun secara umum motivasi mahasiswa, mengalami peningkatan yang maksimal dibandingkan pada kegiatan pra tindakan dan siklus I.

\section{2) Hasil Belajar Mahasiswa}

Adapun hasil tes pembelajaran pada siklus II dapat dilihat pada tabel berikut:

Hasil Belajar Mahasiswa Siklus II

\begin{tabular}{|c|c|c|c|}
\hline No & Nilai & $\mathbf{F}$ & $\%$ \\
\hline 1 & 100 & 2 & 5.56 \\
\hline 2 & 95 & 3 & 8.33 \\
\hline 3 & 90 & 2 & 5.56 \\
\hline 4 & 85 & 9 & 25.00 \\
\hline 5 & 80 & 10 & 27.78 \\
\hline 6 & 75 & 8 & 22.22 \\
\hline 7 & 70 & 1 & 2.78 \\
\hline 8 & 65 & 1 & 2.78 \\
\hline 9 & 60 & 0 & 0.00 \\
\hline 10 & 55 & 0 & 0.00 \\
\hline 11 & 50 & 0 & 0.00 \\
\hline \multicolumn{2}{|c|}{ Jumlah } & 36 & 100.00 \\
\hline
\end{tabular}

bahwa hasil belajar mahasiswa dalam mata kuliah bahasa Arab materi hiwar pada siklus II yang dilaksanakan sebanyak 36 orang mahasiswa menunjukkan bahwa, 34 orang mahasiswa tuntas atau (94,44\%), sedangkan yang tidak tuntas sebanyak 2 orang mahasiswa atau $(5,56 \%)$. Dari data tersebut dapat disimpulkan bahwa hasil belajar pada siklus II mengalami peningkatan dari kegiatan sebalumnya yaitu kegiatan pra tindakan dan siklus I.

\section{3) Refleksi Hasil Tindakan Siklus II}

Refleksi ini dilakukan untuk menentukan apakah tindakan pada siklus II telah mencapai tingkat keberhasilan atau belum. Dalam 
Peningkatan Motivasi dan Hasil Belajar Mahasiswa Pada Mata Kuliah Bahasa Arab Materi Hiwar dengan Menggunakan Metode Role Play Pada Program Studi

Pendidikan Agama Islam Semester II Universitas Muhammadiyah Sumatera Utara (Hasrian Rudi Setiawan)

pelaksanaan kegiatan belajar mengajar pada materi hiwar dengan metode role play, diperoleh informasi dari hasil pengamatan adalah:

a) Berdasarkan hasil observasi, maka motivasi belajar mahasiswa pada siklus II yang paling tinggi adalah aspek minat mencapai $25,97 \%$. Kemudian pada aspek perhatian siswa terhadap penjelasan dosen mencapai $25,70 \%$. Pada aspek partisipasi siswa dalam kegiatan pembelajaran mencapai $24,50 \%$. Dan pada aspek presentasi mencapai $23,83 \%$. Secara umum peningkatan motivasi belajar siswa pada siklus II mengalami peningkatan, yaitu mencapai $85,23 \%$. Dapat diartikan bahwa motivasi mahasiswa dalam mata kuliah bahasa Arab pada materi hiwar dengan menggunakan metode role play, mengalami peningkatan yang maksimal dibandingkan pada kegiatan pra tindakan dan siklus I.

b) Berdasarkan hasil tes belajar siswa pada siklus II diperoleh data bahwa mahasiswa yang mendapat nilai tuntas, yaitu 42 orang mahasiswa atau (95,45\%), sedangkan mahasiswa yang mendapat nilai 100 berjumlah 2 orang mahasiswa. Dengan demikian kriteria keberhasilan pembelajaran telah mencapai kriteria yang telah ditetapkan pada siklus II.

Dari uraian di atas, dapat disimpulkan bahwa pembelajaran tindakan pada siklus II sudah mencapai kriteria yang telah ditetapkan yaitu persentase ketuntasan hasil belajar dan motivasi siswa untuk belajar dengan metode role play telah mencapai ketuntasan.

\subsection{Pembahasan Hasil Penelitian}

Dari hasil temuan yang telah dipaparkan di atas, dapat dikemukakan bahwa Penelitian Tindakan Kelas (PTK) yang dilaksanakan di Program Studi Pendidikan Agama Islam Fakultas Agama Islam UMSU, merupakan salah satu cara untuk menemukan masalah yang ada khususnya pada mata kuliah bahasa Arab. Karena selama ini, mahasiswa kurang berminat dalam mempelajari mata kuliah bahasa Arab khususnya materi hiwar, walaupun dosen telah berusaha untuk memotivasi mahasiswa agar sungguh-sungguh mempelajari materi hiwar namun kenyataannya masih banyak dijumpai mahasiswa yang belum mampu melaksanakannya secara baik dan benar. Dengan demikian sungguh perlu dikembangkan kepada dosendosen yang lain, termasuk mata kuliah yang selama ini dianggap sulit oleh mahasiswa agar dilakukan penelitian tindakan kelas untuk mengungkap masalah yang dihadapi oleh dosen maupun mahasiswa itu sendiri.

Berdasarkan paparan data dan analisis pada bab terdahulu, dapat dikemukakan bahwa ada dua temuan dalam penelitian ini, yaitu: Motivasi belajar mahasiswa Program Studi Pendidikan Agama Islam Fakultas 
Agama Islam UMSU mengalami peningkatan setelah menggunakan metode role play, yaitu pada siklus I peningkatan motivasi mahasiswa mencapai 80,83\% sedangkan peningkatan motivasi mahasiswa pada siklus II mencapai, 85,97\%. Kemudian hasil belajar mahasiswa Program Studi Pendidikan Agama Islam Fakultas Agama Islam UMSU mengalami peningkatan setelah menggunakan metode role play, yaitu hasil belajar mahasiswa pada siklus I hanya 23 orang mahasiswa yang mendapat nilai tuntas atau mencapai $63,89 \%$. Sedangkan pada siklus II hasil belajar mahasiswa mengalami peningkatan dibandingkan dengan siklus I, yaitu mencapai 34 orang siswa yang mendapat nilai tuntas atau mencapai 94,44\%. dengan kriteria ketuntasan minimal dalam belajar sehingga secara klasikal juga mengalami peningkatan hasil belajar dengan batas $85 \%$ ketuntasan klasikal.

Jadi dengan demikian penerapan metode role play dalam pembelajaran materi hiwar telah berhasil dengan baik. Karena itu peneliti menganjurkan bagi dosen-dosen yang mengajarkan mata kuliah bahasa Arab pada materi hiwar sebaiknya menerapkan metode role play, karena dengan pengalaman yang ada selama ini yaitu dengan menerapkan metode ceramah saja ternyata tidak efektif dalam meningkatkan motivasi dan hasil belajar mahasiswa. Dengan demikian hasil penelitian ini menunjukkan bahwa metode role play telah memberikan hasil berupa ketuntasan belajar mahasiswa. Hal ini membuktikan bahwa berdasarkan penelitian ternyata sebagian besar mahasiswa telah menguasai materi pelajaran yang diajarkan.

\section{E. Kesimpulan dan Saran}

\subsection{Kesimpulan}

Berdasarkan hasil dan analisis data hasil penelitian yang telah dijelaskan pada bab sebelumnya, maka dapat dikemukakan kesimpulan penelitian ini, yaitu sebagai berikut:

1. Motivasi belajar mahasiswa

Program Studi Pendidikan Agama Islam Semester II Universitas Muhammadiyah Sumatera Utara mengalami peningkatan setelah menggunakan metode role play, yaitu pada siklus I peningkatan motivasi mahasiswa mencapai 80,83\% sedangkan peningkatan motivasi siswa pada siklus II mencapai, $85,97 \%$.

2. Hasil belajar mahasiswa Program Studi Pendidikan Agama Islam Semester II Universitas Muhammadiyah Sumatera Utara mengalami peningkatan setelah menggunakan metode role play, yaitu hasil belajar mahasiswa pada siklus I hanya 23 orang mahasiswa yang mendapat nilai tuntas atau mencapai $63,89 \%$. Sedangkan pada siklus II hasil belajar mahasiswa mengalami peningkatan dibandingkan dengan siklus I, yaitu mencapai 34 orang mahasiswa 
Peningkatan Motivasi dan Hasil Belajar Mahasiswa Pada Mata Kuliah Bahasa Arab Materi Hiwar dengan Menggunakan Metode Role Play Pada Program Studi

Pendidikan Agama Islam Semester II Universitas Muhammadiyah Sumatera Utara (Hasrian Rudi Setiawan)

yang mendapat nilai tuntas atau mencapai 94,44\%.

Berdasarkan uraian di atas, dapat disimpulkan bahwa pembelajaran tindakan pada siklus II sudah mencapai kriteria yang telah ditetapkan yaitu persentase motivasi dan ketuntasan hasil belajar siswa untuk belajar dengan menggunakan metode role play juga mendukung mencapai ketuntasan.

\subsection{Saran}

Berdasarkan hasil uraian Penelitian Tindakan Kelas (PTK) ini, dan beberapa kesimpulan yang telah diutarakan di atas, ada sejumlah pemikiran yang penulis sarankan yang diharapkan berguna bagi dosen dalam menjalankan fungsinya dan pihak-pihak yang terkait dalam pendidikan, di antaranya:

1. Dengan memperhatikan hakikat dan sifat metode role play sangat berguna untuk meningkatkan motivasi dan hasil belajar mahasiswa, maka disarankan kepada dosen supaya memahami metode pembelajaran dengan meningkatkan kualitas diri, baik dengan cara belajar atau dengan mengikuti pelatihan-pelatihan peningkatan mutu, untuk kemudian diterapkan dalam proses pembelajaran pada mata pelajaran dan aspek yang tepat.

2. Kepada dosen agar dapat meningkatkan kompetensi dalam mengajar dengan melakukan Penelitian Tindakan Kelas (PTK), sehingga akan ditemukan suatu kondisi belajar yang efektif dan meningkatkan hasil belajar khususnya mahasiswa.

3. Rancangan pembelajaran yang dilakukan dalam penelitian tindakan kelas ini belum sepenuhnya sempurna, untuk itu bagi dosen lain yang ingin mengimplementasikannya dalam materi hiwar atau pada materi yang lain hendaknya menelaah terlebih dahulu, sehingga dapat menerapkannya dengan lebih baik.

4. Dalam rangka mencapai tingkat ketepatan penerapan metode role play dalam proses pembelajaran yang lebih inovatif, maka penelitian ini perlu dilanjutkan dengan materi dan pelajaran yang berbeda dan kompetensi yang berfokus pada pendalaman pemahaman, dan keluasan wawasan.

5. Pengambil kebijakan, kiranya mencari jalan keluar untuk meningkatkan kualitas dosen agar mampu mengajar secara profesional dengan memberikan pelatihan-pelatihan secara bertahap dan kontinuitas, sehingga para dosen bisa lebih menguasai strategi belajar yang efektif, juga berusaha melengkapi media pembelajaran sehingga memudahkan dosen menyampaikan materi pelajaran yang akhirnya dapat meningkatkan hasil belajar mahasiswa.

\section{Daftar Pustaka}

Arifin, Z. (2012). Evaluasi Pembelajaran. Jakarta: Direktorat Jendral Pendidikan Islam Kementrian Agama. 
Arikunto, S. (2002). Prosedur Penelitian. Jakarta: PT. Rineka Cipta.

Daradjat, Z. (2008). Metodik Khusus Pengajaran Agama Islam. Jakarta: Bumi Aksara.

Hamalik, O. (2003). Kurikulum dan Pembelajaran. Jakarta: Bumi Aksara.

Hamdani. (2010). Strategi Belajar Mengajar . Bandung: CV. Pustaka Setia.

Hasan, C. (1994). Dimensi-Dimensi Psikologi Pendidikan. Surabaya: Al-Ikhlas.

Huberman, M. B. (1992). Analisis Data Kualitatif. Jakarta: UI Press.

Iskandar. (2009). Penelitian tindakan kelas. Ciputat: Gaung Persada Press.

Iskandar. (2009). Psikologi Pendidikan Sebuah Orientasi Baru. Ciputat: Gaung Persada Press.

Moleong, L. J. (1995). Metodologi Penelitian Kualitatif. Bandung: PT. Remaja Rosdakarya.

Nasution, A.-R. d. (2011). Teori Belajar dan Pembelajaran. Medan: Perdana Publising.

Nasution, S. (1992). Berbagai Pendekatan dalam Proses Belajar Mengajar. Jakarta: Bumi Aksara.

Purwanto, M. N. (1994). PrinsipPrinsip dan Teknik Evaluasi Pengajaran. Bandung: Rosdakarya.

Purwanto, N. (1991). Psikologi Pendidikan . Bandung: Remaja Rosdakarya.

Rosnita. (2007). Evaluasi Pendidikan. Bandung: Ciptapustaka Media.
Sudarsono. (1999). Kamus Filsafat dan Psikologi . Jakarta: Rineka Cipta.

Sudjana, N. (2005). Penilaian Hasil Proses Belajar Mengajar. Bandung: PT. Remaja Rosdakarya.

Uno, H. B. (2008). Teori Motivasi dan Pengukurannya: Analisis Di Bidang Pendidikan . Jakarta: Bumi Aksara.

Uno, H. B. (2010). Model Pembelajaran: Menciptakan Proses Belajar Yang Efektif dan Kreatif. Jakarta: Bumi Aksara.

Winataputra. (2005). Perkembangan Peserta Didik. Jakarta: Universitas Terbuka Depdiknas. 